\title{
Pengembangan Literasi untuk Meningkatkan Minat Baca Siswa di SDN Gladak Anyar IV
}

\author{
Ria Kasanova ${ }^{1}$, Mohammad Rudiyanto ${ }^{2}$ \\ Universitas Madura, Jl Raya Panglegur KM 3,4 Pamekasan Jawa Timur, Indonesia \\ kasanovaria@unira.ac.id
}

\begin{abstract}
The purpose of this study was to describe and analyze the development of the Literacy Culture of SDN Gladak Anyar IV Pamekasan students. This study uses a qualitative descriptive study method using a case study approach. Data collection methods were carried out through interviews, observation, and documentation obtained from school leaders, teachers, and students. Data analysis used an interactive model with data documentation, data visualization and validation. The process of developing a literacy culture is carried out in a three-step process. (1) Planning the development of a literacy culture, then setting goals, compiling programs, formulating strategies, and managing facilities and infrastructure. (2) Implementation of literacy culture development. The implementation of literacy culture development involves competency courses, development and training. (3) Assessment in the form of weekly, monthly and annual assessments. As a result, the results of the development of a literacy culture show that students' reading interest in reading can increase.
\end{abstract}

Keywords: Literacy Culture, Student Interest.

Keywords: Development, Culture, Reading.

\begin{abstract}
Abstrak
Penelitian ini bertujuan untuk mendeskripsikan dan menganalisis perkembangan Budaya Literasi siswa SDN Gladak Anyar IV Pamekasan. Penelitian ini menggunakan metode studi deskripsi kualitatif dengan menggunakan pendekatan studi kasus. Metode pengumpulan data dilakukan melalui wawancara, observasi, dan dokumentasi yang didapatkan dari pimpinan sekolah, guru, dan siswa. Analisis data menggunakan model interaktif dengan dokumentasi data, visualisasi data dan validasi. Proses pengembangan budaya literasi dilakukan dengan proses tiga langkah. (1) Merencanakan pengembangan budaya literasi, selanjutnya menetapkan tujuan, menyusun program, menyusun strategi, dan mengelola sarana dan prasarana. (2) Implementasi pengembangan budaya literasi. Pelaksanaan pengembangan budaya literasi melibatkan kursus kompetensi, pengembangan dan pelatihan. (3) Penilaian berupa penilaian mingguan, bulanan dan tahunan. Hasilnya, hasil pengembangan budaya literasi menunjukkan bahwa minat baca minat baca siswa dapat meningkat.
\end{abstract}

Kata kunci: Budaya Literasi, Minat Siswa.

Copyright (c) 2021 Ria Kasanova, Mohammad Rudiyanto

Corresponding author: Ria Kasanova

Email Address: kasanovaria@unira.ac.id (Jl Raya Panglegur KM 3,4 Pamekasan Jawa Timur)

Received 09 May 2021, Accepted 02 July 2021, Published 03 July 2021

\section{PENDAHULUAN}

Indonesia terpilih sebagai salah satu negara yang berhasil menurunkan angka melek huruf. Menurut data Program Pembangunan PBB (UNDP) sejak 2014, angka melek huruf masyarakat Indonesia adalah 92,8\% untuk dewasa dan 98,8\% untuk remaja. Menurut data UNDP tahun 2014, Indonesia telah mengatasi krisis literasi terkait literasi. Namun tantangan dan puncak yang saat ini kami hadapi adalah menurunnya minat baca masyarakat, termasuk pelajar (Sarveganga, 2017). Minat baca yang rendah tentunya berdampak besar pada buta huruf. Siswa dapat memahami arti dari apa yang mereka baca. Tinjauan terhadap perkembangan International Literacy Survey (PIRLS) 2011 menunjukkan bahwa kemampuan literasi siswa Indonesia masih berada di urutan terbawah 
dibandingkan negara lain. Menurut pemeringkatan PISA (International Student Assessment Program), Indonesia menempati urutan ketiga negara paling rendah dengan skor 371 (Abidin, 2018).

Selain itu, Indonesia menduduki peringkat ke-48 dari 56 negara hasil asesmen OECD 2007 yang berarti Indonesia jauh lebih buruk dibandingkan negara lain. Pada tahun 2009, terdapat 402 hasil asesmen PISA untuk pelajar Indonesia. Indonesia berada di peringkat 57 dari 57 negara yang dievaluasi oleh OECD pada tahun 2010. Hasil untuk tahun 2012 dan 2015 tetap sama. Singkatnya, pemahaman bacaan siswa Indonesia masih kurang (Abden, 2018).

"Budaya literasi Indonesia jauh tertinggal dari negara lain," kata Satalia Dharma, ketua Himpunan Pengembangan Budaya Literasi Indonesia. Hasil Progress in International Literacy Studies (PIRLS) menunjukkan bahwa siswa Indonesia (405) memiliki skor literasi jauh di bawah rata-rata internasional (500). Selain itu, data dari UNESCO (UNESCO) dirilis pada tahun 2012, sehingga minat baca di Indonesia hanya 0,001. Konon, hanya 1 dari 1000 orang yang tertarik membaca dan menulis. Angka melek huruf orang dewasa di Indonesia hanya 65,5\%, sementara Malaysia sekarang 86,4\%, angka UNDP juga mengejutkan. Budaya buta huruf Indonesia tertinggal ketika negara tetangga belajar di luar negeri di Indonesia (Mohammad Merced, 2016).

Hasil studi internasional tersebut menunjukkan bahwa mahasiswa Indonesia yang mewakili masyarakat Indonesia pada umumnya memiliki kemampuan membaca dan menulis yang kurang baik terutama dalam hal kemampuan berbahasa (Kharajmi, 2019). Kasus tersebut segera mendesak pemerintah berbenah agar Indonesia bisa bersaing di kancah internasional. Salah satu upaya dan hasil tersebut adalah pengembangan budaya literasi. Perlunya mendorong budaya literasi diatur dalam Keputusan Menteri Pendidikan dan Kebudayaan Tahun 2015 (Permitandikoud) n. 23 tentang pengembangan diri. Hal ini dicapai dengan wajib membaca khususnya bagi siswa tingkat Sekolah dasar sampai dengan sekolah tinggi berkat dimulainya program atletik sekolah (Permandiknas, 2015). School Literacy Movement (GLS) adalah inisiatif global dan berkelanjutan untuk mengubah sekolah menjadi institusi pendidikan, memungkinkan warga belajar membaca dan menulis seumur hidup melalui keterlibatan sipil (Antasari, 2017). Versi ini menyoroti partisipasi semua pihak yang terlibat dalam dunia pendidikan, mulai dari tingkat pusat, daerah dan regional / perkotaan hingga satuan pendidikan, sekolah (Nurdanti, 2010).

Sekolah berperan penting sebagai alat untuk mempromosikan nilai-nilai budaya dan individualitas bangsa (Tyranto, Fauzia, Hadi, 2019). SDN Gladak Anyar IV Pamekasan merupakan sekolah yang memiliki misi menguasai prinsip-prinsip sains dan melahirkan generasi fisikawan dan kepenelitian yang kuat dari perspektif global. Hal tersebut dapat tercapai apabila kegiatan pendidikan sekolah dapat mendukung pendidikan peserta didik dari perspektif yang lebih luas dan internasional. Salah satu caranya adalah dengan mempromosikan budaya literasi di sekolah (Vulandari, 2017). Menurut komentar peneliti, budaya literasi SDN Gladak Anyar IV Pamekasan tercermin dalam kehidupan sehari-hari siswa sekolah dengan kebiasaan membaca dan mempelajari buku 15 menit sebelum aktivitas lain dimumlai. Selain itu, peneliti dapat menemukan bahwa semua siswa memiliki 
metode yang berbeda-beda dalam literasi sehingga hal ini menjadibudaya merupakan ciri penting sekolah.

SDN Gladak Anyar IV Pamekasan kurang memiliki budaya literasi sehingga penulis berupaya meningkatkan minat baca siswa. Oleh karena itu, dengan adanya permasalahan pada data eksperimen di atas, peneliti menunjukkan minat yang besar terhadap pengembangan budaya literasi, dan hal tersebut dapat menggugah minat siswa untuk belajar siswa SDN Gladak Anyar IV Pamekasan. Pengembangan model perpustakaan dan pusat literasi untuk peningkatan literasi, harus dipandang sebagai pusat gerakan literasi, khususnya bagi kedua guru. Untuk meningkatkan budaya baca. Bukan hanya siswa dan masyarakat umum. Peran aktif komunitas perguruan tinggi dalam mewujudkan budaya literasi di sekolah sangat mendesak (Siroj, 2017).

\section{METODE}

\section{Setting Penelitian}

Jenis penelitian yang digunakan pada penelitian ini adalah jenis studi masalah. Studi kasus adalah galat satu jenis penelitian kualitatif, dimana peneliti melakukan eksplorasi secara mendalam terhadap kualitatif deskriptif merupakan suatu Berangkat dari penekanan masalah dalam penelitian ini, maka pendekatan dalam penelitian ini menggunakan metode penelitian kualitatif deskriptif. Penelitian mendeskripsikan suatu kondisi dengan apa adanya (Sukmadinata, 2013). Terhadap satu atau lebih orang. Suatu masalah terikat oleh saat dan aktivitas dan peneliti melakukan pengumpulan data dan pada saat yang berkesinambungan (Sugiyono, 2013).

\section{Teknik Pengumpulan Data}

Teknik pengumpulan data yang digunakan pada penelitian ini yaitu sebagai berikut:

\section{Observasi}

Observasi adalah teknik pengumpulan data yang dilakukan melalui pengamatan secara peneliti terhadap tanda-tanda-tanda-tanda subyek yang diteliti baik pengamatan itu dilakukan dalam situasi sebenarnya maupun dalam situasi yang khusus diadakan (Arikunto, 2016). Observasi yang digunakan pada penelitian ini merupakan observasi eksklusif. Melalui observasi secara eksklusif peneliti mendapatkan berita yang sesuai dengan keadaan yang sebenarnya pada lapangan sehingga dalam melaksanakan penelitian, peneliti bisa memperoleh data yang lebih valid karena peneliti mengadakan pengamatan di lokasi penelitian secara langsung.

\section{Wawancara}

Wawancara merupakan suatu teknik pengumpulan data dalam sebuah penelitian dengan jalan mengadakan dialog dengan responden. Sementara itu Burhan Bingin mengatakan bahwa wawancara merupakan suatu cara mengumpulkan data atau keterangan menggunakan cara bertatap muka secara langsung dengan informan, dengan maksud mendapatkan gambaran lengkap mengenai topik yang diteliti (Arikunto, 2016). Dalam penelitian ini, peneliti menggunakan teknik wawancara tidak terstruktur. Wawancara tak terstruktur merupakan wawancara yang bersifat luwes, susunan 
pertanyaannya dan susunan kata-kata dalam setiap pertanyaan dapat diubah dalam waktu wawancara, disesuaikan dengan kebutuhan dan kondisi waktu wawancara, termasuk ciri sosial budaya, agama, suku, gender, usia, tingkat pendidikan, dan pekerjaan (Mulyana, 2008).

3. Dokumentasi

Dokumentasi adalah cara pengumpulan data yang berupa bahan tulis. Dibandingkan menggunakan metode lain, maka metode ini tidak begitu sulit, pada artian apabila terdapat kekeliruan, sumber datanya masih tetap (belum berubah). Dengan metode dokumentasi yang diamati bukan benda hidup namun benda mati (Akhmad, 2015). Dokumentasi dipilih supaya dapat memperoleh data langsung menurut loka penelitian misalnya laporan tertulis, peraturanperaturan, laporan kegiatan, fotofoto, rekaman kegiatan, dan data yang relevan dengan konteks penelitian. Teknik dokumentasi ini digunakan peneliti buat memperkuat dan menaikkan keakuratan data yang diperoleh menurut hasil observasi dan wawancara. Sehingga memungkinkan peneliti bisa menafsirkan, memperkuat hasil wawancara dan observasi dan menguji setiap temuan dalam latar penelitian.

\section{Teknik Analisis Data}

Teknik analisis data yang dipakai dalam penelitian ini merupakan adalah reduksi data, penyajian data, dan penarikan kesimpulan/verifikasi (Kurniawan dan Sadjiarto, 2013; Megawati, 2016; Rosa, 2015). Mereduksi data berarti merangkum (Putra, Purwanto, dan Kismartini, 2013), memilih halhal yang pokok, memfokuskan dalam hal-hal yang penting, dicari tema dan pokoknya. Dengan demikian, data yang sudah direduksi akan memberikan gambaran yang lebih jelas, dan mempermudah peneliti melakukan pengumpulan data (Hidayat, 2016) selanjutnya, dan mencarinya jika diperlukan (Riswani dan Widayati, 2012).

Setelah data direduksi, maka langkah selanjutnya yang akan dilakukan adalah mendisplay data. Dalam penelitian kualitatif, penyajian data bisa dilakukan dalam bentuk uraian singkat, bagan interaksi antar kategori, dan sejenisnya. Dengan mendisplay data, maka akan memudahkan memahami apa yang terjadi, merencanakan kerja selanjutnya dari apa yang sudah dipahami tersebut. Selanjutnya pada melakukan display data peneliti mengunakan teks yang naratif (Riswani dan Widayati, 2012). Langkah ketiga dalam analisis data kualitatif adalah penarikan kesimpulan dan verifikasi. Kesimpulan awal yang ditemukan masih bersifat sementara, dan akan berubah bila tidak ditemukan buktibukti kuat yang mendukung pada termin pengumpulan data berikutnya. Tetapi, apabila kesimpulan yang ditemukan yang dikemukakan dalam tahap awal, didukung oleh buktibukti yang valid dan konsisten ketika peneliti pulang ke lapangan mengumpulkan data, maka kesimpulan yang dikemukakan merupakan konklusi yang kredibel (Shanty dan Christiana, 2013; Purnamasari, Yulyana, dan Ramdani, 2016).

\section{HASIL DAN DISKUSI}

\section{Pengembangan Budaya Literasi di SDN Gladak Anyar IV Pamekasan}

Pengembangan budaya literasi di SDN Gladak Anyar IV Pamekasan tidak terlepas dari peran kepala sekolah sebagai pimpinan tertinggi yang memiliki hak dalam mengeluarkan suatu keputusan 
atau kebijakan mengenai suatu program yang harus diimplementasikan pada lingkungan sekolah termasuk mengenai pengembangan budaya literasi di sekolah. Dalam pengembangan budaya literasi pada sekolah, terdapat beberapa tahapan yang dilakukan kepala sekolah, guna buat menaikkan minat membaca siswa. Diantaranya adalah menjadi berikut: Sesuai dengan tujuannya untuk membantu mitra pada meningkatkan kompetensi dan digital skill pengajar sekolah dasar, maka hasil penelitian ini adalah sebagai berikut:

\section{Perencanaan budaya literasi di SDN Gladak Anyar IV Pamekasan}

Pertama, perencanaan budaya literasi di SDN Gladak Anyar IV Pamekasan, Perencanaan dalam pengembangan budaya literasi pada SDN Gladak Anyar IV Pamekasan mempunyai empat aspek yang sebagai perhatian yakni (1) perumusan tujuan, (2) perumusan program, (3) penyusunan strategi, dan (4) pengelolaan sarana dan prasarana pendukung penerapan budaya literasi. Perencanaan adalah hubungan antara apa yang ada sekarang menggunakan bagaimana seharusnya yang bertalian menggunakan kebutuhan, penentuan tujuan, prioritas, dan acara (Uno, 2012). Pertama, tujuan budaya literasi pada SDN Gladak Anyar IV Pamekasan merupakan untuk menanamkan kebiasaan berfikir dan berperilaku ilmiah yang kritis, kreatif dan mandiri (cerdas intelektual/olah pikir). Tujuan tersebut dapat tercapai dengan cara menciptakan dan menyebarkan lingkungan belajar yang simulatif, kreatif, dan menyenangkan.

Kedua, penyusunan acara atau konten pembelajaran. Program-program unggulan yang dirancang buat mencapai tujuan budaya literasi di SDN Gladak Anyar IV Pamekasan merupakan; cerita dongeng, majalah dinding reading group, conversation (dialog), pachelaton (percakapan bahasa jawa), dan pemutaran film pendek yang bertemakan tentang edukasi atau pendidikan.

Ketiga, aktivitas penyusunan taktik pembelajaran yang akan digunakan guru. Penyusunan strategi di SD Negeri 01 Kauman Kota Malang penting buat dilakukan karena menggunakan taktik programprogram pembelajaran yang sudah dirancang dapat diterima oleh peserta didik dengan mudah. Dengan demikian, tujuan yang sudah ditetapkan dapat tercapai secara efektif dan efisien. Strategi pembelajaran digunakan di sekolah untuk mendukung pengembangan budaya literasi dan meningkatkan minat baca siswa. Adapun strategi yang digunakan oleh SDN Gladak Anyar IV Pamekasan adalah sebagai berikut: Jakarta. Berlatih membaca cepat dan membaca prediksi, kritik, dan pengembangan konten. Pemahaman Bacaan Umum (Abden, Pengembangan Kepenelitian, Berdasarkan Pembelajaran Pemahaman Membaca 2012) Strategi-Pertanyaan, Jawaban, MTJ atau Inkuiri (Pertanyaan Membaca) adalah strategi membaca yang muncul untuk mengembangkan pemahaman bacaan yang komprehensif. Dari Membaca Menjadi Pemahaman Membaca dan Memberikan Prediksi Lebih Banyak dalam Membaca (Dalman, 2014) Strategi Mendongeng SDN Gladak Anyar IV Strategi Pemkasan digunakan untuk mempersiapkan siswa mendengarkan cerita.

Keempat, pengelolaan sarana dan prasarana untuk mendukung pengembangan budaya literasi. Sekolah membutuhkan sarana dan prasarana untuk mewujudkan budaya literasi. Sarana dan prasarana dapat membantu Anda mencapai tujuan belajar Anda (Yuliana, 2008). Infrastruktur pendukung SDN 
Gladak Anyar IVPamekasan merupakan bagian dari seluruh rombongan. Mulailah dengan gedung perpustakaan, taman belajar, pojok baca, dan keranjang baca. Selain itu, strukturnya diklasifikasikan sepenuhnya dan mencakup ketersediaan bacaan yang sesuai (manual dan non-manual). Buku teks yang disediakan tidak sembarangan, tetapi dipilih terlebih dahulu untuk membaca pesan moral dalam kehidupan sehari-hari.

2. Implementasi Pengembangan Budaya Literasi di SDN Gladak Anyar IV Pamekasan

Setelah budaya literasi dikembangkan, semua program dilaksanakan dan dilaksanakan untuk mencapai tujuan yang diinginkan. Ada tiga langkah untuk melaksanakan latihan literasi. Langkah ini dapat dijadikan model untuk mengembangkan budaya literasi di sekolah. Ini termasuk (Anderson, 2005):

a. Pembiasaan

Pada tahap pengenalan, kepala sekolah SDN Gladak Anyar IV Pamekasan membuat pedoman bahwa siswa, guru, dan guru harus belajar 15 menit sebelum jam pelajaran. Untuk mendukung kegiatan tersebut, kepala sekolah menciptakan lingkungan fisik untuk sekolah literasi. Menciptakan Perpustakaan yang sangat nyaman. buku yang rapi dengan koleksi buku-buku bagus. Selain itu, fasilitas untuk pembaca dan infrastruktur pendukung lainnya seperti bacaan sudut, troli dan bacaan majalah bulanan, serta membaca buku siswa memberikan hiburan.

\section{b. Pengembangan}

SDN Gladak Anyar IV Pamekasan dikembangkan dengan tujuan untuk meningkatkan pemahaman bacaan siswa. Kegiatan pengembangan SDN Gladak Anyar IV Pamekasan mendorong siswa untuk belajar 15 menit sebelum semester. Membaca dengan keras, membaca dengan keras, dan melakukan hal-hal lain dengan akun non-sekolah. Kegiatannya meliputi percakapan dan percakapan dalam bahasa Inggris, membaca cerita atau dongen yang mengandung nilai nyata bagi siswa, dan membaca buku. Selain itu, siswa akan meningkatkan keterampilan membaca dan menulis melalui kegiatan perpustakaan sekolah dan kunjungan ke perpustakaan kota. Memperhatikan bacaan sudut, bacaan mobil dan film pendek dengan cermat. Menunjukkan kemampuan membaca melalui berbagai aktivitas di perpustakaan sekolah, perpustakaan kota, atau area belajar kelas digital (konten internet).

c. Pengajaran

Pengembangan budaya literasi juga dilakukan dalam proses pembelajaran. Sebelum masuk pada tahap inti pembelajaran, guru meminta siswa untuk membaca materi yang akan diajarkan selama 15 menit sehingga peserta didik memiliki pengetahuan awal terkait dengan materi pembelajaran yang akan disampaikan oleh guru. Hal ini dilakukan untuk mendukung pelaksanaan Kurikulum 2013 yang mensyaratkan peserta didik membaca buku non teks pelajaran yang dapat berupa buku tentang pengetahuan umum, kegemaran, minat khusus, atau teks multiliteral, dan juga dapat dikaitkan dengan mata pelajaran tertentu. Adapun Kegiatan literasi dalam pembelajaran, di sesuaikan dengan tagihan akademik di kurikulum 2013. 
3. Evaluasi Pengembangan Budaya Literasi di SDN Gladak Anyar IV Pamekasan.

SDN Gladak Anyar IV Pamekasan mengulas kegiatan terkini lembaga pengembangan literasi. Selain itu, SDN Gladak Anyar IV Pamekasan mengevaluasi perkembangan kemampuan literasi dan menentukan keberhasilan setiap program atau kegiatan yang dilaksanakan. Dengan cara ini, sekolah dapat menentukan apakah tujuan dan jadwal telah ditetapkan. Mekanisme asesmen SDN Gladak Anyar IV Pamekasan untuk kegiatan pengembangan budaya literasi biasanya dilakukan seminggu sekali. Penilaian rutin dimulai dengan mengevaluasi aktivitas harian Anda dengan mengevaluasi aktivitas mingguan Anda. Setelah instruktur melakukan penilaian, laporan tersebut dipresentasikan kepada kepala sekolah untuk penilaian simultan. Selain penilaian mingguan, SDN Gladak Anyar IV Pamekasan melakukan penilaian bulanan.

Penilaian dilakukan sebulan sekali melalui kegiatan profesional sekolah. Kegiatan ini diselenggarakan untuk mengetahui keberhasilan dan kendala yang dihadapi guru dan siswa dalam menjalankan program satu bulan. Kepala sekolah dan guru bekerja sama untuk menemukan solusi atas masalah. Minat utama dalam melakukan kegiatan asesmen di SDN Gladak Anyar IV Pamekasan terkait dengan berbagai aspek seperti Kinerja guru, faktor yang diberikan kepada siswa, literasi, dan strategi atau metode yang digunakan untuk melakukan pembelajaran. bahan. Hasil asesmen digunakan sebagai pedoman sekolah. Pemantauan dipimpin oleh kepala sekolah pertama, kepala sekolah, dan termotivasi serta berhasil menyelesaikan masalah.

Pengembangan budaya literasi di sekolah SDN Gladak Anyar IV Pamekasan Keberhasilan pengembangan budaya literasi Pamekasan tercermin dari tumbuhnya minat baca anak. Ketika minat baca siswa meningkat, mereka dapat melihat bahwa anak-anak mereka bahagia, penyayang, atau berminat membaca. Dia juga menjelaskan bahwa cinta adalah apa yang disukai dan dicintai orang. Jadi, jika orang tersebut melakukan sesuatu yang penting baginya, dia akan bahagia tanpa hambatan dari luar (Sardiman, 2009). Menurut pengamatan peneliti, siswa SDN Gladak Anyar IV Pamekasan terlihat antusias, energik, gembira dan antusias saat mengikuti program literasi sekolah. Ini menunjukkan bahwa anak-anak bersemangat untuk melanjutkan proses literasi. Ini didasarkan pada visi Slamet dan menunjukkan beberapa indikator tentang apa yang ingin Anda lakukan, termasuk kesenangan, minat, penerimaan, dan keterlibatan siswa (Sardiman, 2009). Mempromosikan budaya literasi dan menggunakan teknologi untuk menyerap informasi. Sementara itu, penelitian ini menyoroti peningkatan minat baca oleh SDN Gladak Anyar IV Pamekasan dan hal baru yang difokuskan untuk menjelaskan dan mempelajari perkembangan budaya literasi. Alhasil, hasil pengembangan budaya literasi menunjukkan bahwa minat baca, minat baca, dan minat baca siswa dapat meningkat. Pengembangan SDN Gladak Anyar IV Pamekasan menerapkan strategi membaca seperti SQ3R, MTJ dan Minta untuk membantu sekolah, kepala sekolah dan guru memahami proses pengembangan budaya literasi. 


\section{KESIMPULAN}

Berdasarkan hasil penelitian peneliti dapat disimpulkan bahwa pengembangan budaya literasi merupakan strategi membaca di SDN Gladak Anyar IV Pamekasan Berisi yang mempengaruhi kecenderungan, pengaruh dan minat membaca siswa. Strategi SQ3R (voting, tanya jawab, membaca, Membaca, menavigasi), strategi / MTJ Q, menanyakan alat dan jawaban (membaca pertanyaan), bercerita, membaca panduan. Kepala sekolah melalui beberapa tahapan dalam mengembangkan budaya literasi di sekolah. Yang pertama tentang perencanaan. Proses yang ditempuh oleh siswa SDN Gladak Anyar IV Pamekasan dilaksanakan untuk mendukung implementasi budaya literasi melalui penetapan tujuan, pengembangan program, pengembangan strategi, serta pengelolaan sarana dan prasarana. Kedua, Menerapkan, atau menjalankan program yang dirancang untuk kompetensi praktis, pengembangan, dan pelatihan. Ini juga merupakan langkah terakhir dalam evaluasi. Penilaian dilakukan untuk memastikan bahwa program literasi dan tujuannya telah tercapai. Kegiatan asesmen biasanya dilakukan seminggu sekali dan sebulan sekali. Memahami budaya literasi yang berubah memudahkan sekolah, kepala sekolah, dan guru untuk mempraktikkan budaya literasi yang berubah. Untuk meningkatkan minat baca siswa, perlu dilakukan sosialisasi budaya literasi di sekolah. Perkembangan yang benar mempengaruhi pencapaian tujuan yang ditetapkan secara efektif dan efisien.

\section{UCAPAN TERIMA KASIH}

Ucapan terima kasih sangat layak disampaikan untuk semua pihak yang telah membantu dalam pengerjaan artikel ini. Baik teman, dosen, kakak, dan yang lainnya. Artikel ini dapat dibuat karena adanya bantuan mereka. Semoga artikel ini dapat bermanfaaat untuk banyak pihak.

\section{REFERENSI}

Abidin, Yunus. 2018. Pembelajaran Literasi Strategi Meningkatkan Kemampuan Literasi Matematika, Sains, Membaca Dan Menulis. Jakarta: Bumi Aksara.

Akhmad, Khabib Alia. 2015. "Pemanfaatan Media Sosial Bagi Pengembangan Pemasaran UMKM (Studi Deskriptif Kualitatif Pada Distro di Kota Surakarta)”. Duta.Com 9, no.1.https://doi.org/20869436.

Anderson, Lorin W. A Taxonomy for Learning, Teaching, and Assesing, A Revision of Bloom"s Taxonomy Of Education Objective. Pearson Education Group, n.d.

Antasari, Indah Wijaya. 2017. "Implementasi Gerakan Literasi Sekolah Tahap Pembiasaan Di MI Muhammadiyah Gandatapa Sumbang anyumas.” LIBRIA 9, no.1. https://doi.org/10.1145/313284 7.3132886.

Dalman. 2014. Keterampilan Membaca. jakarta: Rajawali Pers.

Hidayat, Mansur. 2016. "Model Komunikasi Kyai Dengan Santri Di Pesantren.” Jurnal Komunikasi ASPIKOM 2, no. 6. https://doi.org/10.24329/aspiko m.v2i6.89.

Iskandarwassid, and Dadang Sunendar. 2010. Strategi Pembelajaran Bahasa. Bandung: Rosda Karya. 
Sardiman.2009. Interaksi Dan Motivasi Belajar Mengajar. Jakarta: PT. Raja Grafindo.

Sugiyono.2013. Cara Mudah Menyusun Skripsi, Tesis, Dan Disertasi. bandung: Alfabeta.

Sukmadinata, Nana Syaodih. 2013. Metode Penelitian Pendidikan. Bandung: Rosda Karya.

Yuliana, Lia, and Suharsimi Arikunto. 2008.Manajemen Pendidikan. Yogyakarta: Teras. 